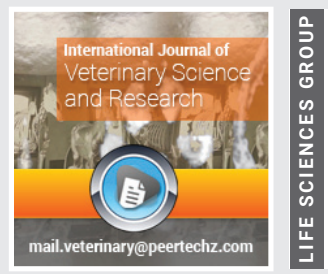

\section{Risk factors influencing the occurrence of anthrax outbreaks at the Livestock- Game interface in Katunguru, Rubirizi district, Uganda}

\author{
Nannozi BK ${ }^{1}$, Kebirungi $\mathbf{P}^{1}$, Asiimwe ${ }^{1}$, Mweheire I' , Ademun \\ $A R^{1}$, Mugaya $\mathrm{H}^{2}$, Ndyamgayo $\mathrm{G}^{2}$, Ndyanabo $\mathrm{S}^{3}$, Ayebazibwe \\ $\mathrm{C}^{3}$, Nizeyimana $\mathrm{G}^{3}$, Okuthe $\mathrm{S}^{3}$ and Magona $\mathrm{JW}^{3 *}$
}

${ }^{1}$ Ministry of Agriculture, Animal Industry and Fisheries, Entebbe, Uganda

${ }^{2}$ Veterinary Department, Rubirizi District, Uganda

${ }^{3}$ Food and Agriculture Organization, Kampala, Uganda
Received: 13 December, 2021

Accepted: 28 January, 2022

Published: 29 January, 2022

*Corresponding author: Magona JW, Food and Agriculture Organization, Kampala, Uganda, Tel: +256 789 429355; Email: Magona.joseph@gmail.com ORCID: https://orcid.org/0000-0002-9062-8277

Keywords: Anthrax; Outbreaks; Risk factors; Participatory epidemiology; Katunguru, Rubirizi district; Uganda

Copyright License: (c) 2022 Nannozi BK, et al. This is an open-access article distributed under the terms of the Creative Commons Attribution License, which permits unrestricted use, distribution, and reproduction in any medium, provided the original author and source are credited.

https://www.peertechzpublications.com

Check for updates

\title{
Abstract
}

Anthrax outbreaks are very frequent and recurrent in the Rubirizi district in landing sites along the Kazinga channel in the Queen Elizabeth National Park in Uganda. This has persistently caused huge losses of domestic and wild animals and increased public health risks to communities. A participatory disease search (PDS) was thus conducted to identify risk factors that influence the recurrent occurrence of the outbreaks. Using PDS tools, including, Focus group discussion, Mapping, Seasonal calendars, Timelines and Pairwise ranking, local communities were engaged to recall detailed information regarding previous anthrax outbreaks. The number of persons that participated in focus group discussions ranged from 16 in Kazinga landing site to 22 in Katunguru, 18 in Kashaka landing site and 20 in Kishenyi landing site The findings revealed anthrax outbreaks had been reported previously in Katunguru, Kyabakara, Katera, Kingu and Ryeyu sub-counties of Rubirizi district that lie within or adjacent to the Queen Elizabeth National Park. The last anthrax outbreak occurred in 2014. Death of goats and sheep and wild animals, especially, hippopotami was reported in the landing sites of Kazinga, Katunguru, Kishenyi and Kashaka in Katunguru Subcounty. Uganda Wildlife Authority (UWA) established burial sites for carcasses of dead hippopotami in Kazinga and Kishenyi landing sites.

Key risk factors associated with anthrax outbreaks (see attached ranks) in Rubirizi district included: (1) Frequent droughts and associated floods (2.5); (2) Dwelling in landing sites normally used as burial areas for carcasses of dead animals by Uganda Wildlife Authority (2.8); (3) Free movement of goats and sheep and intermingling with wildlife at landing sites along Kazinga channel (3.0); (4) Community habit of eating the meat of dead wild or domestic animals (3.8); (5) Communities eating not wellcooked meat (4.0); (6) Ignorance among communities regarding anthrax and its mode of spread (4.8); (7) Frequent migration of communities from landing sites with low to those with a high risk of anthrax disease (6.5); (8) Grazing domestic animals in close proximity with wildlife in the Game Park (6.8); (9) Communities consuming game meat (8.0); and (10) Frequent occurrence of anthrax outbreaks and spread of anthrax spores through floods and existing water bodies (8.3).

In conclusion, the PDS case study successfully identified risk factors associated with anthrax outbreaks in Katunguru Subcounty of Rubirizi district in Uganda. Sensitization of communities on anthrax, its mode of spread and effective and sustainable control was recommended in order to contain anthrax outbreaks.

\section{Introduction}

Anthrax is a highly fatal infectious zoonotic disease caused by the spore-forming bacterium Bacillus anthracis. It is also gram-positive, aerobic, and encapsulated [1]. Its clinical manifestation, include, sudden death (often within 2 or 3 hours of being apparently normal); and very occasionally some animals show trembling, a high temperature, difficulty breathing, collapse and convulsions before death. This usually occurs over a period of 24 hours; after death blood may not clot, resulting in a small amount of bloody discharge from the nose, mouth and other openings and carcass stiffness $[2,3]$. Confirmation of diagnosis depends on detection of (1) Rod-shaped bacteria surrounded by a capsule visible in blood 
smears made from surface blood vessels, (2) If a carcass is opened accidentally, the spleen is usually swollen and there is bloodstained fluid in all body cavities [2,3].

At the continental level in Africa, anthrax outbreaks were reported by 18 countries, including, Uganda in 2014 with a total of 744 outbreaks, 199,912 susceptible animals, 4,004 cases and 1,477 mortalities [4]. The highest number of outbreaks was reported by Ethiopia ( 498 outbreaks), followed by South Africa (145 outbreaks) and Zimbabwe (23 outbreaks). Most of the outbreaks were reported from March to May [4]. Within the East African Community, Kenya reported the highest number of outbreaks (20 outbreaks), followed by South Sudan (8 outbreaks), then Uganda ( 2 outbreaks) and Tanzania (1 outbreak) in 2014 [4].

Recent reports from Uganda, indicated the occurrence of anthrax outbreaks in Arua district, with 672 livestock deaths and 4-5 livestock carcasses showing signs of anthrax; Kween district with 14 livestock deaths; and Kiruhura district with 35 livestock deaths and 8-9 livestock carcasses showing signs of anthrax [5]. Anthrax outbreaks have been reported in Queen National Park in Uganda among wildlife in 1959, 1962 and 1991 and 2004-2005 [6]. During the outbreak in 2004-2005, 306 hippopotami represented 11.63\%, 63 zebras representing $1.47 \%$, 60 buffaloes representing $0.9 \%$, thirteen warthogs representing $0.69 \%$, twelve kobs representing $0.07 \%$, three waterbucks representing $0.09 \%$ and five elephants representing $0.02 \%$ died [6].

Anthrax outbreaks in Western Uganda in Rubirizi district, especially in landing sites in sub-counties along the Kazinga channel in the Queen Elizabeth National Park, are very frequent and recurrent leading to loss of domestic and wild animals in affected areas and increased public health risk.

Regarding management of anthrax outbreaks, OIE regulations as specified in the Terrestrial Animal Health Code [7]. Have to be followed and the disease is notifiable. All reports require implementation of ring vaccination, quarantine of meat and milk products and strict movement control of animals for at least 20 days after the latest outbreak. In wildlife, surveillance followed by appropriate disposal of carcasses is the operative management strategy [6].

Hence, a participatory disease search was undertaken in the Rubirizi district for purposes of clear understanding of the risk factors influencing the recurrent outbreaks. This could guide how to best manage or prevent anthrax outbreaks.

\section{Materials and methods}

\section{Study area}

The study was conducted in the Rubirizi district that borders Kabarole in the North. Bushenyi district in the East. Queen Elizabeth National Park and Kasese district in the West. Lake Edward and Rukungiri district in the South. Rubirizi district has an estimated livestock population of 500,000 cattle and 400,000 shoats. The district has a sub-humid climate. It receives an annual rainfall of $1000-1500 \mathrm{~mm}$ and has daily mean temperatures ranging between $18^{\circ} \mathrm{C}$ (minimum) and $30{ }^{\circ} \mathrm{C}$ (maximum). The vegetation is high-altitude forests on hills and savannah grassland interspersed with bushy shrubs within the Western Rift valley. Much of the district is densely populated and most farmers practice mixed crop-livestock farming with specialized dairy farmers keeping Friesian crosses under either fenced farms or zero-grazing (stallfeeding). Pastoral herds consisting of mainly Ankole cattle do graze on bushy communal pastures within the Rift Valley at the interface with the Queen Elizabeth National Park.

\section{Selection of study sites}

The District Veterinary Officer selected the study sites using a risk-based approach according to the history of Anthrax outbreaks. Initially, four sub-counties , including, Katunguru, Kyabakara, Katera, Kingu, and Ryeyu lying in the Rift Valley plains, adjacent to the Queen Elizabeth National Park were considered. However, it was noted that Katunguru Subcounty lies in the plains of the Rift Valley and has the waters of Kazinga channel and abundant grazing wildlife intermingling with livestock at landing sites, especially goats and sheep, was at the highest risk of anthrax outbreaks. Hence all landing sites in the Katunguru sub-county, including, Katunguru, Kisenyi, Kashaka and Kazinga were selected for the study.

One focus group discussion was conducted in each of the landing sites of Kashaka, Kazinga, Kishenyi and Katunguru. The number of persons that participated in focus group discussions ranged from 16 in Kazinga landing site to 22 in Katunguru, 18 in Kashaka landing site and 20 in Kishenyi landing site. Mapping was carried out in Kazinga, Katunguru, Kishenyi and Kashaka landing sites. The community mapping exercise depicted burial sites in Kazinga and Kishenyi landing sites for carcasses of dead animals, especially Hippopotami that died during anthrax outbreaks Figure 1.

\section{Study design}

The study design employed a Participatory Disease Search/ Participatory Epidemiology (PDS/PE) approach $[8,9]$. A team from the Ministry of Agriculture, Animal Industry and Fisheries conducted informal interviews of key informants. The key informants interviewed included, the District Veterinary Officer, District Health Inspector, Animal husbandry Officer at the district, the Monitoring and Research Department of Queen Elizabeth National Park and the Acting in Charge for Kishenyi Health Centre. Available secondary data was as well collected. For purposes of clear understanding during interviews, a case definition for Anthrax had the following major clinical signs: sudden death with bleeding from all orifices of the carcass without clotting and stiffness of carcasses. On undertaking confirmatory diagnosis, rod-shaped bacteria surrounded by a capsule will be visible in blood smears made from surface blood vessels.

\section{Participatory Disease Search tools}

Focus group discussion was very key in assessing the memory of the communities about the past anthrax outbreaks, knowledge of the disease, risk factors associated with anthrax, 


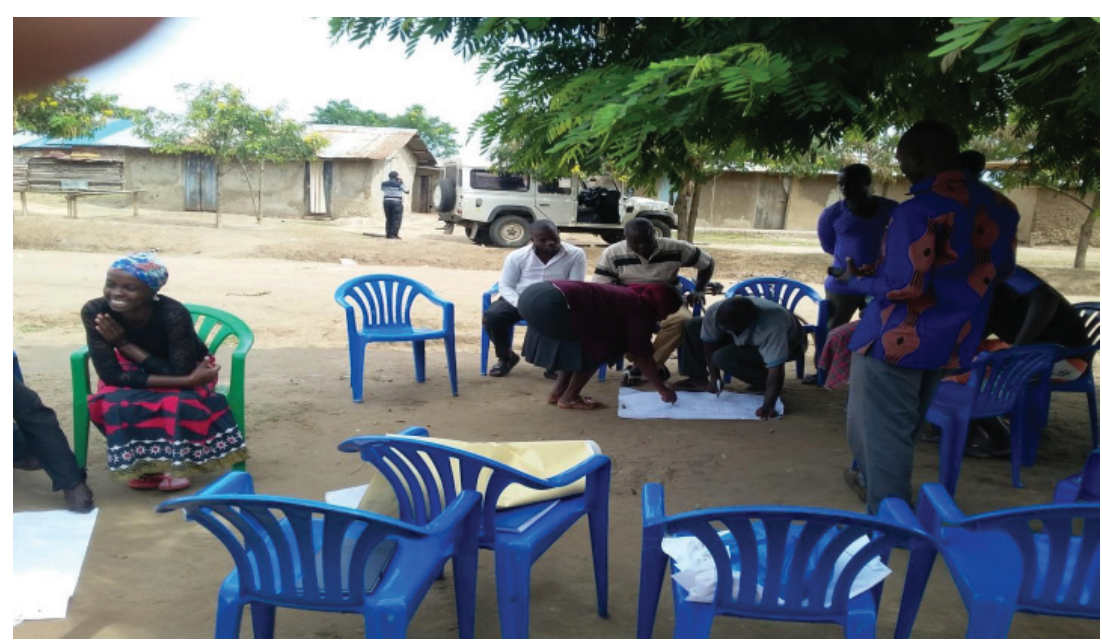

Figure 1: Mapping exercise during a focus group discussion at Kazinga landing site, Rubirizi District, Uganda.

measures taken at the time to control the outbreak and any other relevant information. Mapping was undertaken for livestock distribution, burial sites for the dead anthrax carcasses, grazing locations, Queen Elizabeth National Park boundaries, densely populated areas or trading centers, Lake (L. George and L. Edward) boundaries, roads, and location of the 2014 anthrax outbreak. Seasonal Calendars were used to explore migrations from one landing site to another due to changes in fishing activities; Dry and rainy seasons; and seasons associated with anthrax outbreaks occur. Timelines were used to explore the events in the past that could have been associated with the anthrax outbreak in the past but very little information was picked as most people had lost memory of such events. The pairwise ranking was used to rank anthrax risk factors as picked from key Informant interviews and Focus group discussions based on their importance/ impact.

The checklist for a Participatory Anthrax Disease Search elaborated the following:(1) Avoiding mentioning Anthrax before the communities; (2) Introducing the appraisal team as an animal health appraisal; (3) Identifying the respondents and establishing if they residents at landing site; (4) Establishing their main herding locations (mapping); (5) Identifying the current disease problems among their livestock in their landing sites. If sudden death of goats, sheep or cattle with bleeding from all orifices of the carcasses without clotting and stiffness of carcasses were mentioned, then Anthrax was explored for in details; (6) Identifying current livestock problems in their landing sites; (7) Historically what the most important disease problems of livestock were in their landing sites- Invariably Anthrax was expected to be mentioned in the response to this question if the communities had experienced outbreaks then; (8) Whether they had personally seen Anthrax cases in their lifetimes and what it looked like; (9) When was the last time their livestock were affected by Anthrax and where it came from; and (10) What conditions favored the occurrence of anthrax outbreaks. In addition, further probing questions were to be added to cross-check reports made in other interviews, coupled with defining climatic patterns and uncontrolled movement of livestock which did affect the epidemiology of anthrax or that contrasted outbreaks with previous outbreaks in regard to the severity of anthrax.

\section{Data storage and analysis}

The data obtained from the participatory methods was entered and stored in Microsoft Excel software. For data analysis, descriptive statistics was performed using GENSTAT (GENSTAT ${ }^{\circledR}$, Version 13).

\section{Results}

Figure 2 shows scores of anthrax risk factors as per perceptions of communities interviewed at Kazinga, Kashaka, Kishenyi and Katunguru landing sites in Rubirizi district, Uganda. Frequent droughts and associated floods (Ds) was considered an important anthrax risk factor as per community scores in Kashaka (score 9), Kishenyi (score 7.5), Kazinga (score 6) and lastly Katunguru (scored 5).

Dwelling in landing sites normally used as burial areas for carcasses of dead animals (B) was considered an important anthrax risk factor as per community scores in Kazinga (score 9), Katunguru (score 9), Kishenyi (score 5) and Kashaka (score 4).

Free movement of goats and sheep and intermingling with wildlife at landing sites along the Kazinga channel $(\mathrm{P})$ was considered an important anthrax risk factor as per community scores in Kishenyi (score 8.5), Kashaka (score 6), Kazinga (score 5) and Katunguru (score 5).

Community habit of eating the meat of dead wild or domestic animals (D) was considered an important anthrax factor as per community scores in Katunguru (score 7), Kazinga (score 6), Kishenyi (score 4.5) and Kashaka (score 4).

Communities eating not well-cooked meat ( $\mathrm{R})$ was considered an important anthrax risk factor as per community scores in Kazinga (score 7), Katunguru (score 7), Kishenyi (score 7), Kishenyi (score 4.5) and Kashaka (score 3).

Ignorance among communities regarding anthrax and its 


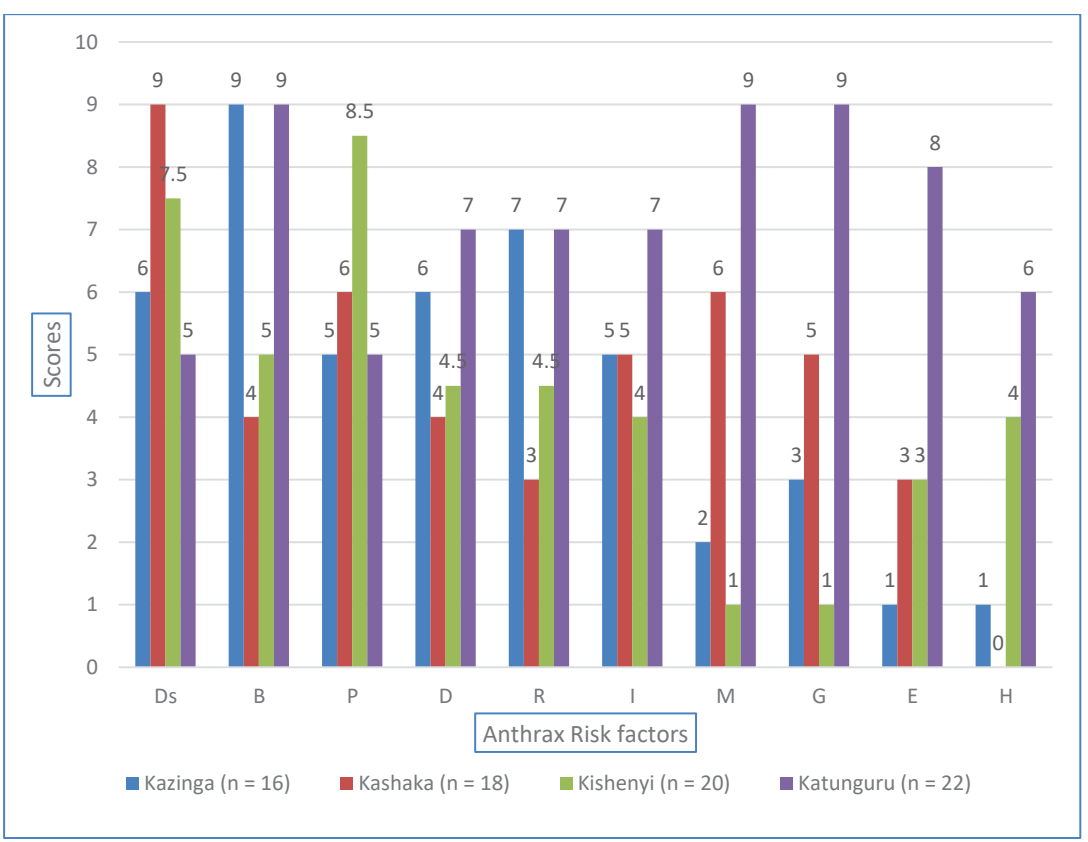

Figure 2: Scores of anthrax risk factors as per perceptions of communities interviewed at Kazinga, Kashaka, Kishenyi and Katunguru landing sites in Rubirizi district, Uganda. Anthrax Risk factors as per perceptions of communities interviewed

Frequent droughts and associated floods (Ds)

Dwelling in landing sites normally used as burial areas for carcasses of dead animals by Uganda Wildlife Authority (B)

Free movement of goats and sheep and intermingling with wildlife at landing sites along the Kazinga channel (P)

Community habit of eating the meat of dead wild or domestic animals (D)

Communities eating not well-cooked meat ( $\mathrm{R})$

Ignorance among communities regarding anthrax and its mode of spread (I)

Frequent migration of communities from landing sites with low to those with high risk of anthrax disease (M) Grazing domestic animals in close proximity with wildlife in

the Game Park (G)

Communities consuming game meat (E)

Frequent occurrence of anthrax outbreaks and spread of anthrax spores through floods and existing water bodies $(\mathrm{H})$.

mode of spread (I) was considered an important anthrax risk factor as per community scores in Katunguru (score 7), Kazinga (score 5), Kashaka (score 5), and Kishenyi (score 4).

Frequent migration of communities from landing sites with low to those with high risk of anthrax disease (M) Grazing domestic animals in close proximity with wildlife in the Game Park (G)was considered an important anthrax risk factor in Katunguru (score 9), Kashaka (score 5), Kazinga (score 3) and Kishenyi (score 1).

Communities consuming game meat (E) was considered an important anthrax risk factor in Katunguru (score 8), Kashaka (score 3), Kishenyi (score 3) and Kazinga (score 1).

Frequent occurrence of anthrax outbreaks and spread of anthrax spores through floods and existing water bodies $(\mathrm{H})$ was considered an important anthrax risk factor in Katunguru (score 6), Kishenyi (score 4) and Kazinga (score 1).

Table 1 is shown the mean scores and ranks of risk factors associated with anthrax outbreaks distributed according to the landing sites. Risk factors were ranked as follows: Frequent droughts and associated floods (2.5), Dwelling in landing sites normally used as burial areas for carcasses of dead animals by Uganda Wildlife Authority (UWA) (2.8), Free movement of goats and sheep intermingling with wildlife at landing sites along
Kazinga channel (3.0), Community habit of eating the meat of dead wild or domestic animals (3.8), Communities eating not well-cooked meat (4.0), Ignorance among communities regarding anthrax and its mode of spread (4.8), Frequent migration of communities from landing sites with low to those with a high risk of anthrax disease (6.5), Grazing domestic animals in close proximity with wildlife in the Game Park (6.8), Communities consuming game meat (8.0) and Frequent occurrence of anthrax outbreaks and spread of anthrax spores through floods and existing water bodies (8.3).

Table 2 shows the pairwise ranking of risk factors associated with anthrax outbreaks by communities living in Kazinga landing site. Dwelling in landing sites normally used as burial areas for carcasses of dead animals by Uganda Wildlife Authority had the highest total score (9), followed by communities eating not well-cooked meat (7) and then frequent droughts and associated floods (6) and community habit of eating the meat of dead wild or domestic animals (6).

Table 3 shows the pairwise ranking of risk factors associated with anthrax outbreaks by communities living in the Kashaka landing site. Frequent droughts and associated floods had the highest total score (9), followed by frequent migration of communities from landing sites with low to those with a high risk of anthrax disease (6) and free movement of goats and 
Table 1: Overall mean scores and ranking of the identified risk factors associated with anthrax outbreaks.

\begin{tabular}{|c|c|c|c|c|c|c|c|c|c|c|}
\hline \multirow[t]{2}{*}{ Risk factors } & \multicolumn{2}{|c|}{$\begin{array}{l}\text { Kazinga landing } \\
\text { site }\end{array}$} & \multicolumn{2}{|c|}{$\begin{array}{l}\text { Kashaka landing } \\
\text { site }\end{array}$} & \multicolumn{2}{|c|}{$\begin{array}{l}\text { Kishenyi landing } \\
\text { site }\end{array}$} & \multicolumn{2}{|c|}{$\begin{array}{l}\text { Katunguru landing } \\
\text { site }\end{array}$} & \multicolumn{2}{|c|}{ Overall mean } \\
\hline & Scores & Rank & Scores & Rank & Scores & Rank & Scores & Rank & Scores & Rank \\
\hline Frequent droughts and associated floods (Ds) & 6 & 3 & 9 & 1 & 7.5 & 2 & 5 & 4 & 6.9 & 2.5 \\
\hline $\begin{array}{l}\text { Dwelling in landing sites normally used as burial areas for carcasses of dead } \\
\text { animals by Uganda Wildlife Authority (B) }\end{array}$ & 9 & 1 & 4 & 6 & 5 & 3 & 9 & 1 & 6.8 & 2.8 \\
\hline $\begin{array}{l}\text { Free movement of goats and sheep and intermingling with wildlife at landing } \\
\text { sites along the Kazinga channel }(P)\end{array}$ & 5 & 5 & 6 & 2 & 8.5 & 1 & 5 & 4 & 6.1 & 3.0 \\
\hline Community habit of eating the meat of dead wild or domestic animals (D) & 6 & 3 & 4 & 6 & 4.5 & 4 & 7 & 2 & 5.4 & 3.8 \\
\hline Communities eating not well-cooked meat ( $\mathrm{R})$ & 7 & 2 & 3 & 8 & 4.5 & 4 & 7 & 2 & 5.4 & 4.0 \\
\hline Ignorance among communities regarding anthrax and its mode of spread (I) & 5 & 5 & 5 & 4 & 4 & 6 & 5 & 4 & 4.8 & 4.8 \\
\hline $\begin{array}{l}\text { Frequent migration of communities from landing sites with low to those with } \\
\text { high risk of anthrax disease (M) }\end{array}$ & 2 & 8 & 6 & 2 & 1 & 9 & 2 & 7 & 2.8 & 6.5 \\
\hline Grazing domestic animals in close proximity with wildlife in the Game Park (G) & 3 & 7 & 5 & 4 & 1 & 9 & 2 & 7 & 2.8 & 6.8 \\
\hline Communities consuming game meat ( $\mathrm{E}$ ) & 1 & 9 & 3 & 8 & 3 & 8 & 2 & 7 & 2.3 & 8.0 \\
\hline $\begin{array}{l}\text { Frequent occurrence of anthrax outbreaks and spread of anthrax spores through } \\
\text { floods and existing water bodies }(\mathrm{H})\end{array}$ & 1 & 9 & 0 & 9 & 4 & 6 & 0 & 9 & 1.3 & 8.3 \\
\hline
\end{tabular}

Table 2: Pairwise ranking of risk factors associated with anthrax outbreaks in Kazinga landing site.

\section{Risk factors}

Community habit of eating the meat of dead wild or domestic animals (D)

Grazing domestic animals in close proximity with wildlife in the Game Park (G)

Communities consuming game meat $\mathrm{E}$

Ignorance among communities regarding anthrax and its mode of spread (I)

Frequent migration of communities from landing sites with low to those with a high risk of anthrax disease (M)

Frequent occurrence of anthrax outbreaks and spread of anthrax spores through floods and existing water bodies $(\mathrm{H})$

Frequent droughts and associated floods (Ds)

Free movement of goats and sheep and intermingling with wildlife at landing sites along the Kazinga channel $(P)$

Communities eating not well-cooked meat $(R)$

\begin{tabular}{|l|l|l|l|l|l|l|l|l|}
\hline D & D & I & D & D & Ds & D & D & B \\
\hline & E & I & G & G & G & P & R & B \\
\hline & I & M & H & Ds & P & R & B \\
\hline & & I & I & Ds & P & R & B \\
\hline & & M & Ds & P & R & B \\
\hline & & & Ds & P & R & B \\
\hline & & & & Ds & R & B \\
\hline & & & & & R & B \\
\hline
\end{tabular}

Dwelling in landing sites normally used as burial areas for carcasses of dead animals by Uganda Wildlife Authority (B)

Total Scores

\begin{tabular}{l|l|l|l|l|l|l|l|l|l|l|}
6 & 3 & 1 & 5 & 2 & 1 & 6 & 5 & 7 & 9
\end{tabular}

Table 3: Pairwise ranking of risk factors associated with anthrax outbreaks in Kashaka landing site.

\section{Risk factors}

Community habit of eating meat of dead wild or domestic animals (D)

Grazing domestic animals in close proximity with wildlife in the Game Park (G)

Communities consuming game meat $(\mathrm{E})$

Ignorance among communities regarding anthrax and its mode of spread (I)

Frequent migration of communities from landing sites with low to those with a high risk of anthrax disease (M)

Frequent occurrence of anthrax outbreaks and spread of anthrax spores through floods and existing water bodies $(\mathrm{H})$

Frequent droughts and associated floods (Ds)

Free movement of goats and sheep and intermingling with wildlife at landing sites along the Kazinga channel (P)

Communities eating not well-cooked meat ( $R$ )

Dwelling in landing sites normally used as burial areas for carcasses of dead animals by Uganda Wildlife Authority (UWA) (B)

Total Scores

\begin{tabular}{|l|l|l|l|l|l|l|l|l|l|}
\hline $\mathbf{D}$ & $\mathbf{G}$ & $\mathbf{E}$ & I & M & H & Ds & P & R & B \\
\hline & G & D & I & M & D & Ds & P & D & D \\
\hline & G & G & M & G & Ds & P & G & B \\
\hline & & I & M & E & Ds & P & E & E \\
\hline & & M & I & Ds & P & I & I \\
\hline & & & M & Ds & P & M & B \\
\hline & & & & Ds & P & R & B \\
\hline & & & & & Ds & Ds & Ds \\
\hline & & & & & & R & B \\
\hline
\end{tabular}

sheep and intermingling with wildlife at landing sites along Kazinga channel (6).

Table 4 is shown a pairwise ranking of risk factors associated with anthrax outbreaks by communities living in the Kishenyi landing site. Free movement of goats and sheep and intermingling with wildlife at landing sites along the Kazinga channel had the highest score (8.5), followed by frequent droughts and associated floods (7.5) and dwelling in landing sites normally used as burial areas for carcasses of dead animals by Uganda Wildlife Authority (UWA) (5).

Citation: Nannozi BK, Kebirungi P, Asiimwe, Mweheire I, Magona JW , et al. (2022) Risk factors influencing the occurrence of anthrax outbreaks at the LivestockGame interface in Katunguru, Rubirizi district, Uganda. Int J Vet Sci Res 8(1): 015-022. DOI: https://dx.doi.org/10.17352/ijvsr.000106 
Table 5 shows the pairwise ranking of risk factors associated with anthrax outbreaks by communities living in the Katunguru landing site. Dwelling in landing sites normally used as burial areas for carcasses of dead animals by Uganda Wildlife Authority (UWA) had the highest total score (9), followed by Communities eating not well-cooked meat (7) and Community habit of eating the meat of dead wild or domestic animals (7).

\section{Discussion}

We report on a participatory disease search that was conducted in the Rubirizi district with the aim of identifying risk factors that influence the frequent and recurrent anthrax outbreaks. Key informant interviews confirmed that anthrax outbreaks had been reported previously in Katunguru, Kyabakara, Katera, Kingu and Ryeyu sub-counties of Rubirizi district that lie within or adjacent the Queen Elizabeth National Park. Previous reports indicate that anthrax outbreaks involving wildlife occurred in Queen Elizabeth National Park in Uganda in 1959, 1962, 1991 and 2004-2005 [6].

Frequent droughts and associated floods as a risk factor are in line with the fact that anthrax outbreaks are associated with high rains followed by dry conditions. Under such conditions the number of spores increases and the herbivores become infected. It has been recognized that spores of. Bacillus anthracis float on water, which causes their dispersion in wet conditions, followed by concentration when dry conditions occur $[1,10,11]$. Reports from Australia suggest that anthrax outbreaks are associated with a long dry spell with high humidity and higher than normal soil temperatures after a preceding wet winter in a poorly drained area where operations were performed to renovate irrigated pasture, water channels and drainage systems [10].

Dwelling in landing sites normally used as burial areas for carcasses of dead animals by the Uganda Wildlife Authority was a risk factor. This could be explained by the fact that in such sites there is a high concentration of spores of Bacillus anthracis. It is highly probable that such places have an ideal condition such as soil rich in nitrogen and organic matter, with pH above 6 [11]. Given the burial of carcasses of dead animals. Anthrax may persist in the environment for many years after contamination of a pasture. Environmental persistence appears to be related to a number of factors, including high levels of soil nitrogen and organic content, a pH level higher than 6.0, and ambient temperature higher than $15^{\circ} \mathrm{C}$. Drought or heavy rains trigger spore germination and bacterial multiplication.

Table 4: Pairwise ranking of risk factors associated with anthrax outbreak in Kishenyi Landing site.$$
\text { Risk factors }
$$

\begin{tabular}{l|l|l|l|l|l|l} 
D & G & E & I & M & H & Ds
\end{tabular}

\begin{tabular}{l|l|l|l|l|l|l|l|l|l} 
D & E & I & D & H & Ds & P & D/R & D
\end{tabular}

Community habit of eating the meat of dead wild or domestic animals (D)

Grazing domestic animals in close proximity with wildlife in the Game Park (G)

Communities consuming game meat $(\mathrm{E})$

Ignorance among communities regarding anthrax and its mode of spread (I)

Frequent migration of communities from landing sites with low to those with a high risk of anthrax disease (M)

Frequent occurrence of anthrax outbreaks and spread of anthrax spores through floods and existing water bodies

Frequent droughts and associated floods (Ds)

Free movement of goats and sheep and intermingling with wildlife at landing sites along the Kazinga channel $(P)$

Communities eating not well-cooked meat ( $R$ )

\begin{tabular}{l|l|l|l|l|l|l|l|l} 
E & I & M & G & Ds & P & R & B
\end{tabular}

\begin{tabular}{l|l|l|l|l|l|l} 
I & $E$ & $H$ & Ds & $P$ & R & B
\end{tabular}

\begin{tabular}{l|l|l|l|l|l}
\hline I & $H$ & Ds & P & R & B
\end{tabular}

\begin{tabular}{l|l|l|l|l}
\hline H & Ds & P & R & B
\end{tabular}

\begin{tabular}{l|l|l|l} 
Ds & $\mathrm{P}$ & $\mathrm{H}$ & $\mathrm{H}$
\end{tabular}

P/Ds Ds Ds

Dwelling in landing sites normally used as burial areas for carcasses of dead animals by Uganda Wildlife Authority (UWA) (B)

Total Scores

Table 5: Pairwise ranking of risk factors associated with anthrax outbreaks in Katuguru Landing Site.

\section{Risk factors}

\begin{tabular}{|l|l|l|l|l|l|l|l|l|l|}
\hline D & G & E & I & M & H & Ds & P & R & B \\
\hline & D & D & I & D & D & D & D & D & B \\
\hline & E & I & G & G & Ds & P & R & B \\
\hline & & I & M & E & Ds & P & R & B \\
\hline & & I & I & Ds & P & R & B \\
\hline & & & M & Ds & P & R & B \\
\hline & & & & Ds & P & R & B \\
\hline & & & & & Ds & R & B \\
\hline & & & & & & & R & B \\
\hline
\end{tabular}

Community habit of eating the meat of dead wild or domestic animals (D)

Grazing domestic animals in close proximity with wildlife in the Game Park (G)

Eating wild meat ( E)

Ignorance among communities regarding anthrax and its mode of spread (I)

Frequent migration of communities from landing sites with low to those with a high risk of anthrax disease (M)

Frequent occurrence of anthrax outbreaks and spread of anthrax spores through floods and existing water bodies $(\mathrm{H})$

Frequent droughts and associated floods (Ds)

Free movement of goats and sheep and intermingling with wildlife at landing sites along the Kazinga channel (P)

Communities eating not well-cooked meat $(\mathrm{R})$

Dwelling in landing sites normally used as burial areas for carcasses of dead animals by Uganda Wildlife Authority (UWA) (B)

Total Scores 
This is important in maintaining the organism in potentially infectious quantities [12].

Free movement of goats and sheep and intermingling with wildlife at landing sites along the Kazinga channel creates a condition of little pasture. Such a shortage of grass forces animals to graze closer to the soil, potentially exposing animals to anthrax spores [13]. Indeed most pastures at landing sites were overgrazed. Grazing on forage plants contaminated by spores leads livestock to acquire gastrointestinal anthrax that results into subsequent systemic dissemination.

The community habit of eating the meat of dead wild or domestic animals or communities eating not well-cooked meat were revealed in Rubirizi district as some of the risk factors influencing the occurrence of anthrax outbreaks. In Uganda, especially in districts of Arua and Kween, people are reported to get anthrax by handling contaminated animal or animal products, consuming undercooked meat of infected animals and intentional release of spores [5]. In line with this, postmortem examinations of suspected anthrax cases (including any cow that has died suddenly for no apparent reason) is not recommended until a blood smear has proved negative $[2,3]$.

Ignorance among communities regarding anthrax and its mode of spread was noted as one of the risk factors. Not having sufficient knowledge regarding such an infectious public health hazard has led to fatal consequences associated with anthrax in Arua and Kween districts [5]. Such as not observing the required burial of anthrax carcasses, eating anthrax carcasses or opening up such carcasses leading to accidental release of spores.

Frequent migration of communities from landing sites with low to those with a high risk of anthrax disease was noted to be one of the risk factors. The migration of fishermen from one landing site to another is normally influenced by fishing activities. However, some of the landing sites such as Kishenyi and Kashaka have a high risk of anthrax outbreaks as a result of having a high concentration of anthrax spores due to having burial sites for dead domestic and wild animal carcasses [6]. Other landing sites such as Kazinga and Katunguru had a low risk of anthrax outbreaks because were not burial sites for anthrax dead carcasses of domestic and wild animals.

Grazing domestic animals in close proximity with wildlife in the Game Park was noted to be one of the risk factors. Increased grazing pressure on pastures shared by domestic and wild animals led to pasture shortage and grazing of animals closer to the soil making them potentially exposed to anthrax spores [13]. Bacillus anthracis also spends much of its life cycle in the ground [14]. Anthrax doesn't typically spread from animal to animal nor from person to person. The bacteria normally produce spores in contact with oxygen. It is mainly a disease of herbivores, with sheep, goats, cattle, and, to a lesser degree, swine but can also be seen in people exposed to tissue from infected animals, contaminated animal products or directly exposed to B. anthracis spores under certain conditions [12].

Communities consuming game meat per se might not increase the risk of contracting anthrax but handling or consuming anthrax contaminated game meat is the risk factor [5].

Frequent occurrence of anthrax outbreaks and spread of anthrax spores through floods and existing water bodies has been suggested to be a risk factor. Spores of Bacillus anthracis normally float on water, which causes their dispersion in wet conditions, followed by concentration when dry conditions occur [10].

In conclusion, the PDS case study successfully identified risk factors for anthrax outbreaks in the Katunguru Subcounty of Rubirizi district. It is therefore recommended that sensitization of communities on anthrax, its mode of spread and effective control be sustained; and (2) an anthrax control project be instituted in order to contain Anthrax outbreaks.

\section{Acknowledgment}

We are grateful to Dr. Darius Musasizi Mwesigye and Dr. Henry Mugaya of Rubirizi district for their cooperation and support during the Participatory Disease Search. In addition, we thank Dr. Anna Rose Ademun Okurut, The Commissioner of Animal Health, in the Ministry of Agriculture, Animal Industry and Fisheries for allowing the study to be conducted. Equally, we thank Dr. Dorris Kiconco, Principal Veterinary Officer in the Ministry of Agriculture, Animal Industry and Fisheries for her logistic support. The Management of the Uganda Wildlife Authority within the Queen Elizabeth National Park is acknowledged for their permission to allow the team to visit and conduct interviews on landing sites. We appreciate the guidance and input offered by Dr. Joseph W. Magona, the FAO PDS/PE Consultant Mentor. We are grateful to Dr. Sam Okuthe for his technical guidance and support of the study. The technical and financial support provided by the Food and Agriculture Organization of the United Nations in Uganda is highly appreciated.

\section{References}

1. Hart CA, Beeching NJ (2002) A spotlight on anthrax. Clinical Dermatology 20 365-375. Link: https://bit.ly/3Hb2Z24

2. Anthrax (2019a) Anthrax-Beef Cattle Research Council.

3. Anthrax (2019b) Anthrax - The Cattle Site

4. Paaryb (2014) Pan African Animal Resources Year Book

5. CDC (2018) Experts Team Up to Tackle Deadly Anthrax Across Ugand. Link: https://bit.ly/32HXSaG

6. Mapesa Moses Wafula, Atimnedi Patrick, Tumwesigye Charles (2007) Managing the 2004/05 anthrax outbreak in Queen Elizabeth and Lake Mburo National Parks, Uganda, African J Ecology. Link: https://bit.ly/3G8CEjT

7. OIE (2011) OIE regulations as specified in the Terrestrial Animal Health Code.

8. Catley Andy, Berhanu Admassu (2003) Using Participatory Epidemiology to Assess the Impact of Livestock Diseases. FAO-OIE-AU/IBAR-IAEA Consultative Group Meeting on Contagious Bovine Pleuropneumonia in Africa 12-14 November 2003, FAO Headquarters, Rome, Italy. Link: https://bit.ly/32DHKXA

9. Saskia H, Masry El, Atef M, Aref N, Fatma Z, et al. (2011) A manual for 
practitioners in community-based animal health outreach (CAHO) for highly pathogenic avian influenza. Link: https://bit.ly/3r6JVw5

10. Turner AJ, Galvin JW, Rubira RJ, Condron RJ, Bradley T (1999) Experiences with vaccination and epidemiological investigations on an anthrax outbreak in Australia in 1997. J Appl Microbiol 87: 294-297. Link: https://bit.ly/3r9iPVt

11. Schild AL, Sallis ESV, Priebe AP, Soares MP, Almeida MB, et al. (2006) Anthrax in cattle in southern Brazil: 1978-2006. Pesquisa Veterinária Brasileira 26(4):243-248. Laboratório Regional de Diagnóstico, Faculdade de Veterinária Universidade Federal de Pelotas, Campus Universitário s/n, Pelotas, RS 96010 900. Link: https://bit.ly/3u5SXvg
12. Kaufmann AF (1990) Observations on the occurrence of anthrax as related to soil type and rainfall. Salisbury Medical Bulletin, 68S: 16-17.

13. Parkinson $R$, Rajic A, Jenson $C$ (2003) Investigation of an anthrax outbreak in Alberta in 1999 using a geographic information system. Can Vet J 44: 315318. Link: https://bit.ly/32DRmBC

14. Schuch R, Fischetti VA (2009) The secret life of the anthrax agent Bacillus anthracis: Bacteriophagemediated ecological adaptations. PLoS ONE 4 e6532. Link: https://bit.ly/3uc8Xf
Discover a bigger Impact and Visibility of your article publication with Peertechz Publications

\section{Highlights}

* Signatory publisher of ORCID

* Signatory Publisher of DORA (San Francisco Declaration on Research Assessment)

* Articles archived in worlds' renowned service providers such as Portico, CNKI, AGRIS, TDNet, Base (Bielefeld University Library), CrossRef, Scilit, J-Gate etc.

* Journals indexed in ICMJE, SHERPA/ROMEO, Google Scholar etc.

* OAI-PMH (Open Archives Initiative Protocol for Metadata Harvesting)

* Dedicated Editorial Board for every journal

* Accurate and rapid peer-review process

* Increased citations of published articles through promotions

- Reduced timeline for article publication

Submit your articles and experience a new surge in publication services (https://www.peertechz.com/submission). 